INFINITY-Jurnal Matematika dan Aplikasinya (IJMA)

Volume 1 | Nomor 2 | Maret|2021

\title{
Faktor-Faktor yang Mempengaruhi Rumah Tangga Miskin Menggunakan Regresi Dummy Di Desa Cilallang Kecamatan Kamanre Kabupaten Luwu
}

\section{Asrirawan', Muhammad llyas ${ }^{2}$}

\section{Corespondensi Author}

IUniversitas Sulawesi Barat, Majene, Indonesia

2Universitas Cokroaminoto Palopo, Fakultas Keguruan dan Ilmu Pendidikan, Palopo, Indonesia

1[Email: asrirawan@unsulbar.ac.id] 2[Email: muhammadilyas@uncp.ac.id]
Abstrak. Tujuan dari penelitian ini adalah untuk mengetahui karakteristik rumah tangga miskin di Desa Cilallang Kecamatan Kamanre Kabupaten Luwu yang dilihat dari beberapa faktor-faktor yang mempengaruhinya. Data yang diperoleh dari $30 \mathrm{kk}$, terdapat lima variabel bebas $(X)$ yaitu jumlah anak $\left(X_{1}\right)$, Usia $\left(X_{2}\right)$, jenis kelamin $\left(D_{1}\right)$, pendidikan terakhir $\left(E_{1}, E_{2}\right)$ dan pekerjaan $\left(F_{1}, F_{2}\right)$ dan satu variabel terikat $(Y)$ yaitu jumlah penghasilan. Model regresi yang digunakan adalah regresi dummy dengan dua variabel penelitian yaitu variabel respon dan variabel prediktor. Dimana regresi dummy untuk data kategorik, tedapat Kabupaten/Kota yang memiliki nilai peluang (probability) dan $\beta$ yang berbeda-beda yang dilihat dari setiap variabel bebas yang memiliki nilai positif dan negatif. Hasil regresi menggunakan regresi dummy untuk variabel Dummy Pendidikan terakhir (El) yaitu 0,462 untuk nilai peluang (probability) dan $\beta_{1}$ yaitu sebesar 131520,078 . Kemudian Dummy Pekerjaan (F1) yaitu 0,241 untuk nilai peluang (probability) dan untuk nilai $\beta_{2}$ yaitu sebesar 674744,194, dummy untuk variabel Pendidikan terakhir (E2) yaitu 0,031 untuk nilai peluang (probability) dan $\beta_{3}$ yaitu sebesar 337921,600, dummy pekerjaan untuk pekerjaan F2 yaitu 0,912 untuk nilai peluang (probability) sedangkan nilai $\beta_{4}$ sebesar $-5133,811$, Usia (X2) dengan nilai peluang (probability) 0,836 dan nilai $\beta_{5}$ sebesar 2309,409 , dan Jumlah anak (X1) dengan nilai pelvang (probability) 0,427 dan nilai $\beta_{6}$ sebesar $-26599,069$. Dan untuk jenis kelamin (D1) dengan nilai peluang (probability) 0,645 dan untuk nilai $\beta_{7}$ sebesar $-117974,727$. Sehingga dapat dikatakan bahwa terjadi ketidakmerataan jumlah penghasilan perbulan yang ada di Kabupaten/Kota pada wilayah tersebut. 


\section{PENDAHULUAN}

Kemiskinan merupakan sebuah permasalahan sosial yang sangat kompleks dan harus segera mendapat formula yang tepat agar dapat terurai. Indonesia sebagai negara dan memiliki jumlah penduduk yang besar tidak dapat terhindar dari masalah tersebut. Ini dibuktikan dengan jumlah penduduk miskin yang begitu besar, yang mayoritas tinggal di pedesaan yang sulit untuk diakses. Kemiskinan dapat diartikan sebagai dimana seseorang sangat sulit untuk memenuhi kebutuhan hidupnya sehari-hari dikarenakan sebagai penyebab salah satunya adalah rendahnya tingkat pendapatan yang diperoleh (Suhardjo, 1997).

Jumlah penduduk miskin di Indonesia relatif masih sangat besar. Berdasarkan data dari SUSENAS yang dikeluarkan pada bulan maret 2012 mengambarkan bahwa penduduk miskin di Indonesia jumlahnya sangat besar. Tercatat pada tahun 2007 berjumlah 37,168.3 juta penduduk miskin pada tahun 2008 turun menjadi 34,963.3 juta. Namun pada tahun 2009 hingga 2012 jumlah penduduk miskin di Indonesia cenderung mengalami penurunan yang berjumlah 29.132.40 juta. Hasil tersebut tercapai karena adanya peran yang dilakukan oleh pemerintah dalam mengatasi kemiskinan yang ada di Indonesia (Suhardjo, 1997).

Kabupaten Luwu Utara merupakan salah satu daerah dengan komposisi penduduk yang multi etnis, agama dan budaya yang terdiri dari penduduk asli (Luwu), pendatang (Bugis, Makassar dan Toraja). Dan para pendatang atas program pemerintah melalui transmigrasi (Jawa, Bali, dan Lombok). Secara umum menyebar pada semua Kecamatan sedang para pendatang menyebar pada dataran rendah yang subur dan daerah pesisir. Sementara pendatang dari etnis Jawa, Bali dan Lombok terkonsentrasi pada tiga Kecamatan masing-masing Kecamatan Bone-Bone, Sukamaju dan Mappedeceng dengan mata pencaharian mayoritas bergerak pada sektor pertanian (BPS Luwu Utara, 2013).

Kemajemukan penduduk ini membawa konsekwensi dengan terjadinya pembauran (assimilasi) budaya dan sosial antar etnis, termasuk perkawinan, pengalaman usaha perdagangan dan pertanian (BPS Luwu Utara, 2013). Jumlah Penduduk Kabupaten Luwu Utara pada tahun 2011 data hasil Sensus penduduk 2011 tercatat 290.365 yang terdiri dari laki-laki sebanyak 146.312 jiwa dan perempuan sebanyak 144.053 jiwa. Dengan laju pertumbuhan penduduk per tahun 1,26\%. Pertumbuhan penduduk setiap tahun terus meningkat harus menjadi perhatian pemerintah dalam perencanaan pembangunannya. Jumlah penduduk tersebut terbagi habis kedalam 68.904 rumah tangga, dimana rata-rata jumlah anggota rumah tangga sebanyak 4 jiwa. Kecamatan Bone-Bone merupakan kecamatan dengan jumlah penduduk terbesar yaitu sebesar 46.364 jiwa. Sedangkan yang terkecil adalah Kecamatan Rampi, sebesar 2.912 jiwa. Kepadatan penduduk rata-rata di Luwu Utara sebesar 39 jiwa $/ \mathrm{Km}^{2}$ (BPS Luwu Utara, 2013).

Kesejahteraan merupakan aspek penting dari kualitas manusia secara keseluruhan. Krisis ekonomi dan moneter yang melanda Indonesia pada tahun 1997 menyebabkan kemunduran berbagai kegiatan ekonomi, terganggunya kegiatan produksi dan distribusi. Permasalahan tersebut membawa dampak yang serius pada peningkatan jumlah pengangguran dan penduduk miskin. Kemiskinan seringkali dipahami sebagai gejala rendahnya tingkat kesejahteraan semata, padahal kemiskinan merupakan gejala yang bersifat kompleks dan multidimensi, dimana berkaitan dengan aspek sosial, ekonomi, budaya, dan aspek lainnya. Berbagai upaya dan kebijakan pembangunan telah dilakukan pemerintah untuk menanggulangi kemiskinan. Seperti inpres desa tertinggal, 
pemberian BLT (Bantuan Langsung Tunai), raskin, kompensasi BBM, dan berbagai program penanggulangan kemiskinan lainnya. Namun, dari berbagai program yang telah dilaksanakan oleh pemerintah tersebut, masih terdapat kekurangan-kekurangan dalam pelaksanaannya.

Secara garis besar, kebutuhan rumah tangga dapat dikelompokkan dalam dua kategori besar, yaitu kebutuhan pangan dan non pangan. Secara alamiah kuantitas pangan yang dibutuhkan seseorang akan mencapai titik maksimum sementara kebutuhan non pangan, tidak akan ada batasnya. Semakin tinggi pengeluaran untuk pangan, berarti semakin kurang sejahtera rumah tangga yang bersangkutan. Sebaliknya, semakin kecil pangsa pengeluaran pangan, maka rumah tangga tersebut semakin sejahtera (Mulyanto, 2005). Pengeluaran rumah tangga dapat menjadi ukuran kesejahteraan, makin besar pengeluaran untuk bahan non pangan menandakan semakin sejahtera kehidupan rumah tangga tersebut (BPS Sumut, 2004). Kota Malang merupakan salah satu kota besar di Jawa Timur dengan tingkat kepadatan penduduk yang tinggi. Kota Malang juga memiliki nilai pengeluaran perkapita per bulan yang cukup besar diantara kabupaten/kota di Jawa Timur. Pada tahun 2009, nilai pengeluaran perkapita per bulan Kota Malang mencapai 45,85\% untuk nilai pengeluaran perkapita sebesar Rp $500.000,00$ ke atas dan 39,48\% untuk nilai pengeluaran perkapita antara Rp 300.000,00 sampai Rp 499.999,00. Hal ini menunjukkan bahwa tingkat kesejahteraan rumah tangga di Kota Malang cukup tinggi.

Kajian mengenai kesejahteraan telah banyak dilakukan, diantaranya oleh Faturokhman dan Molo (1995) yang meneliti tentang karakteristik rumah tangga miskin di Yogyakarta dan Rahmawati (1999) meneliti kesempatan kerja penduduk miskin di DKI Jakarta. Kemudian Badan Pusat Statistik (BPS) bekerja sama dengan Word Bank Institute (2002) menyusun dasar-dasar analisis kemiskinan. Penelitian mengenai kesejahteraan tersebut mengindikasikan bahwa banyak sekali faktor yang mempengaruhi kesejahteraan rumah tangga. Oleh karena itu, dilakukan penelitian mengenai klasifikasi kesejahteraan rumah tangga di Kota Malang guna melihat karakteristik dan faktor yang berpengaruh terhadap kesejahteraan rumah tangga di Kota Malang. Ada beberapa penelitian sebelumnya yang berkaitan dengan klasifikasi kesejahteraan rumah tangga, yaitu penelitian Prakosa (2011) mengenai klasifikasi kesejahteraan rumah tangga di Provinsi Jawa Timur dengan pendekatan Bootstrap Aggregating Classification and Regression Trees. Dalam penelitiannya, Prakosa hanya menggunakan tujuh variabel prediktor sebagai faktor yang mempengaruhi kesejahteraan rumah tangga di Jawa Timur. Penelitian lainnya adalah Pratama (2011) mengenai klasifikasi kesejahteraan rumah tangga di Jawa Timur dengan pendekatan Multivariate Adaptive Regression Spline-Bootstrap Aggregating. Berbeda dengan Prakosa, Pratama menggunakan tujuh belas variabel prediktor sebagai faktor yang mempengaruhi kesejahteraan rumah tangga di Jawa Timur. Pada penelitian ini juga digunakan tujuh belas variabel prediktor yang mencakup aspek kependudukan, pendidikan, perumahan, ketenagakerjaan, sosial ekonomi rumah tangga, dan teknologi informasi dan komunikasi sebagai faktor yang mempengaruhi kesejahteraan rumah tangga di Kota Malang. Namun, metode analisis yang digunakan adalah regresi logistik. Regresi logistik digunakan untuk mengetahui pola hubungan kesejahteraan rumah tangga di Kota Malang dengan faktor-faktor yang mempe-ngaruhinya. Selain itu, dengan analisis regresi logistik dapat diketahui nilai ketepatan klasifikasi kesejahteraan rumah tangga di Kota Malang. Namun, nilai ketepatan klasifikasi tersebut dapat ditingkatkan dengan pendekatan bagging regresi logistik. Oleh karena itu, untuk memperoleh ketepatan klasifikasi yang lebih tinggi digunakan pendekatan bagging regresi logistik. Paramita (2008) telah melakukan penelitian dengan 
dengan menggunakan bagging regresi logistik ordinal untuk memperoleh ketepatan klasifikasi yang lebih tinggi. Sosial ekonomi yang memungkinkan bagi setiap warga negara untuk dapat memenuhi kebutuhan yang bersifat jasmani, rohani, dan sosial sesuai dengan harkat dan martabat manusia.

Kesejahteraan menurut Cahyat dkk. (2007) merupakan kondisi dapat memenuhi kebutuhan dasar baik material maupun non material yang mencakup aspek gizi dan kesehatan, pengetahuan, dan kekayaan materi. Kemiskinan sendiri merupakan bentuk ketidakmampuan untuk meraih kesejahteraan dipandang dari sisi ekonomi dalam memenuhi kebutuhan dasar makanan dan bukan makanan yang diukur dari sisi pengeluaran. Penduduk miskin adalah penduduk yang memiliki rata-rata pengeluaran perkapita per bulan di bawah Garis Kemiskinan (GK). Garis kemiskinan merupakan penjumlahan dari Garis Kemiskinan Makanan (GKM) dan Garis Kemiskinan Non Makanan (GKNM). Untuk tahun 2009, garis kemiskinan telah ditentukan oleh BPS, yaitu Rp 200.262,00 (BPS, 2009). Penduduk yang memiliki rata-rata pengeluaran perkapita per bulan di bawah garis kemiskinan dikategorikan sebagai penduduk miskin. Selain itu, kemiskinan juga dijelaskan sebagai suatu situasi dimana seseorang atau rumah tangga mengalami kesulitan untuk memenuhi kebutuhan dasar, sementara lingkungan pendukungnya kurang memberikan peluang untuk meningkatkan kesejahteraan secara berkesinambungan atau untuk keluar dari kerentanan (Cahyat dkk, 2007). Tingkat kesejahteraan masyarakat antara lain dapat diukur melalui besarnya pendapatan/pengeluaran. Pengeluaran untuk kebutuhan konsumsi dapat mencerminkan tingkat kemampuan ekonomi masyarakat, dan kemampuan daya beli masyarakat dapat memberikan gambaran tentang tingkat kesejahteraan masyarakat. Semakin tinggi daya beli masyarakat, menunjukkan meningkatnya kemampuan dalam memenuhi kebutuhan hidupnya dan selanjutnya akan berdampak meningkatnya kesejahteraan masyarakat (BPS, 2009).

Berdasarkan latar belakang di atas, dibuat rumusan masalah untuk penelitian ini yaitu Faktor-faktor apa saja yang mempengaruhi kemiskinan di Desa Cilallang, Kec. Kamanre, Kab. Luwu dengan menggunakan model Regresi Dummy. Sedangkan tujuan penelitian ini adalah Untuk mengetahui faktor-faktor apa saja yang mempengaruhi kemiskinan yang ada di Desa Cilallang, Kec. Kamanre, Kab. Luwu.

\section{METODE}

Data yang digunakan dalam penelitian ini adalah data kuisioner/angket tentang kemiskinan di Desa Cilallang, Kecamatan Kamanre, Kabupaten Luwu. Jumlah rumah tangga miskin yang akan diambil sebagai sampel sebanyak 30 kepala keluarga.

Variabel penelitian yang digunakan terdiri atas 2 macam yaitu, variabel respon dan variabel prediktor. Variabel respon adalah jumlah penghasilan perbulan sedangkan variabel prediktor yang akan digunakan adalah status migrasi, jenils kelamin, umur, jumlah anak, pendidikan, serta pekerjaan.

Tahapan-tahapan yang dilakukan dalam penelitian ini adalah sebagai berikut:

1. Menyebarkan angket penelitian

2. Melakukan analisis deskriptif variabel penelitian

3. Melakukan pemodelan kemiskinan menggunkan analisis regresi Dummy dengan menggunakan software SPSS

\section{HASIL DAN PEMBAHASAN}

Dalam regresi variabel Dummy, tingkat kemiskinan terhadap pengaruh jumlah kemiskinan pada jumlah anak, usia, jenis kelamin, Pendidikan terakhir dan pekerjaan. 
Berdasarkan data yang diperoleh, akan dibentuk suatu model analisis regresi dummy dengan menggunakan Software SPSS yang menghasilkan nilai Coefficients pada Tabel 1 berikut:

Tabel 1. Hasil analisis data Coefficients rumah tangga miskin Desa Cilallang Kecamatan Kamanre Kabupaten Luwu

\begin{tabular}{|c|c|c|c|c|c|}
\hline \multicolumn{6}{|c|}{ Coefficients } \\
\hline Model & $\begin{array}{l}\text { Unstandardized } \\
\text { Coefficients }\end{array}$ & & $\begin{array}{l}\text { Standardized } \\
\text { Coefficients }\end{array}$ & $\mathrm{t}$ & Sig. \\
\hline & B & Std. Error & Beta & & \\
\hline Constant & 1634768,890 & 996385,576 & & 1,641 & 116 \\
\hline PendidikanTerakhir & 337921,600 & 145827,894 & ,570 & 2,317 & ,031 \\
\hline Pekerjaan & $-697619,501$ & 425412,749 & $-1,029$ & $-1,640$ & 116 \\
\hline Usia & 2309,409 & 11018,195 & 049 & 210 & 836 \\
\hline Jumlahanak & $-26599,069$ & 32868,069 &,- 161 &,- 809 & ,427 \\
\hline D1 & $-117974,727$ & 252624,609 & -117 &,- 467 & 645 \\
\hline E1 & 131520,078 & 175356,121 & 146 & 750 & 462 \\
\hline E2 & 337921,600 & 145827,894 & ,570 & 2,317 & ,031 \\
\hline F1 & $-674744,194$ & 559414,604 &,- 756 & $-1,206$ & 241 \\
\hline F2 & $-5133,811$ & 45834,189 &,- 023 &,- 112 & ,912 \\
\hline
\end{tabular}

Tabel 1 adalah hasil analisis data rumah tangga miskin Desa Cilallang Kecamatan Kamanre Kabupaten Luwu. Yang pertama kali dilihat adalah nilai signifikan dari $\beta$ untuk variabel Dummy pendidikan terakhir (E1) yaitu 0,462 untuk nilai signifikan dan $\beta_{1}$ yaitu sebesar 131520,078. Kemudian Dummy Pekerjaan (F1) yaitu 0,241 untuk nilai signifikan dan untuk nilai $\beta_{2}$ yaitu sebesar-674744,194, Dummy untuk variabel pendidikan terakhir (E2) yaitu 0,031 untuk nilai signifikan dan $\beta_{3}$ yaitu sebesar 337921,600, Dummy pekerjaan untuk pekerjaan F2 yaitu 0,912 untuk nilai signifikan sedangkan nilai $\beta_{4}$ sebesar -5133,811, usia (X2) dengan nilai signifikan 0,836 di beri nilai $\beta_{5}$ sebesar 2309,409 , dan jumlah anak (X1) dengan nilai signifikan 0,427 dan nilai $\beta_{6}$ sebesar 26599,069 . Dan untuk jenis kelamin (D1) dengan nilai signifikan 0,645 dan untuk nilai $\beta_{7}$ sebesar $-117974,727$.

Hipotesisnya adalah:

$\mathrm{H}_{0}$ : Nilai $\beta$ sama dengan nol

$\mathrm{H}_{1}$ : Nilai $\beta$ tidak sama dengan nol.

Maksud dari $\beta$ sama dengan nol adalah jika tidak menolak nol maka nilai $\beta$ dari variabel pendidikan terakhir tidak ada (karena sebenarnya nilai nol, bukan 131520,078.

Seperti biasa, significance level-nya adalah 0,05 dengan 9-tailed. Dari angka signifikan pada tabel 3 untuk variabel Dummy Pendidikan terakhir adalah 0,031, karena nilainya dibawah 0,05 dari Pendidikan terakhir maka tolak $\mathrm{H}_{0}$ atau nilai dari Dummy Pendidikan terakhir tidak sama dengan nol, artinya ada pengaruh Pendidikan terakhir dengan jumlah penghasilan di Desa Cilallang Kecamatan Kamanre Kabupaten Luwu. Kemudian untuk Dummy pekerjaan adalah 0,116 dan 0,241, karena 0,116 dan 0,241 diatas 0,05 maka terima $\mathrm{H}_{1}$ atau nilai dari Dummy pekerjaan sama dengan nol. Begitu pula dengan usia, jumlah anak dan jenis kelamin dimana nilai signifikan dari usia yaitu 0,836, jumlah anak 0,427dan jenis kelamin 0,645. Dari ketiga variable tersebut memiliki nilai signifikan diatas 0,05 maka terima $\mathrm{H}_{1}$ atau nilai dari usia, jumlah anak, dan jenis kelamin sama dengan nol atau tidak ada pengaruh terhadap jumlah penghasilan di Desa Cilallang Kecamatan Kamanre Kabupaten Luwu.

Untuk variabel dummy, pendidikan terakhir sama dengan nol, maka variabel dummy Pendidikan terakhir tidak mempengaruhi jumlah penghasilan terhadap rumah 
tangga miskin di Desa Cilallang Kecamatan Kamanre Kabupaten Luwu, sedangkan untuk variabel dummy pekerjaan, usia, jumlah anak, dan jenis kelamin tidak sama dengan nol maka variable pekerjaan, usia, jumlah anak dan jenis kelamin mempengaruhi jumlah penghasilan rumah tangga miskin di Desa Cilallang Kecamatan Kamanre Kabupaten Luwu.

Dari hasil analisis pada Tabel 1 Coefficients selanjutnya dapat dilihat hasil analisis Model Summary pada Table 2 berikut:

Tabel 2. Hasil analisis data Model Summary rumah tangga miskin Desa Cilallang Kecamatan Kamanre Kabupaten Luwu

\begin{tabular}{lcccc}
\hline & \multicolumn{3}{c}{ Model Summary } \\
\hline Model & $\mathrm{R}$ & R Square & $\begin{array}{c}\text { Adjusted } \\
\text { R Square }\end{array}$ & Std. Error of the Estimate \\
\hline 1 &, $707^{\mathrm{a}}$ &, 500 &, 309 & 376572,98018 \\
\hline
\end{tabular}

Pada Tabel 2, dapat dilihat dari nilai $R$ Square (atau $\mathrm{R}^{2}$ ) bahwa besarnya dependent bisa dijelaskan oleh independent. Ini ditunjukkan dengan angka 0 sampai 1 . Tabel 2 dengan nilai $\mathrm{R}^{2}$-nya adalah 0,500 . Artinya adalah nilai jumlah penghasilan (dependent variable) bisa dijelaskan oleh dummy pendidikan terakhir, dummy pekerjaan, usia, jumlah anak dan jenis kelamin (independent variable) sebesar 50\%. Sedangkan sisanya $50 \%$ dapat dijelaskan sebab-sebab lain. Seperti yang dijelaskan sebelumnya, tidak ada jumlah minimal untuk $\mathrm{R}^{2}$ ini. Angka $\mathrm{R}$ sebesar 0,707 menunjukkan angka korelasi yang besar antara penghasilan perbulan dengan Pendidikan terakhir, pekerjaan, usia, jumlah anak dan jenis kelamin.

Tabel 3. Hasil analisis data ANOVA rumah tangga miskin Desa Cilallang Kecamatan Kamanre Kabupaten Luwu

\begin{tabular}{llllll}
\hline \multicolumn{5}{l}{ ANOVA } \\
\hline Model & Sum of Squares & df & Mean Square & F & Sig. \\
\hline Regression & 2976715269295,636 & 8 & $372089408661,9542,624$ &, $037^{\mathrm{b}}$ \\
1 Residual & 2977951397371,029 & 21 & 141807209398,620 & \\
Total & 5954666666666,665 & 29 & & & \\
\hline
\end{tabular}

Berdasarkan Tabel 3 ANOVA diketahui bahwa nilai $F_{\text {hitung }}$ adalah sebesar 2,624 dengan signifikan sebesar 0,037. Angka ini lebih besar dibanding nilai $\alpha=0,05$ sehingga dapat dikatakan bahwa pengaruh variable pendidikan terakhir, pekerjaan, usia, jumlah anak dan jenis kelamin berpengaruh secara signifikan terhadap penghasilan perbulan pada rumah tangga miskin di Desa Cilallang Kecamatan Kamanre Kabupaten Luwu.

Berdasarkan data tersebut, diperoleh persamaan regresi dummy sebagai berikut:

$$
Y=\beta_{0}+\beta_{1} X_{1}+\beta_{2} X_{2}+\beta_{3} D_{1}+\beta_{4} E_{1}+\beta_{5} E_{2}+\beta_{6} F_{1}+\beta_{7} F_{2}+\varepsilon
$$

Pada persamaan regresi dummy yang diperoleh dari tabel 1 Coefficients adalah sebagai berikut:

$$
\begin{gathered}
Y=1634768,890-26599,069 \mathrm{X}_{1}+2309,409 \mathrm{X}_{2}-117974,727 \mathrm{D}_{1}+131520,078 \mathrm{E}_{1} \\
+337921,600 \mathrm{E}_{2}-674744,194 \mathrm{~F}_{1}-5133,811 \mathrm{~F}_{2}+\varepsilon
\end{gathered}
$$

Pada persamaan terlihat bahwa koefisien regresi dummy dari setiap variable bebas memiliki nilai yang positif dan negatif. Sehingga dapat diartikan bahwa variable bebas $X_{1}, X_{2}, D_{1}, E_{1}, E_{2}, F_{1}, F_{2}$ yang memiliki koefisien regresi yang positif menunjukkan bahwa antara $X_{1}, X_{2}, D_{1}, E_{1}, E_{2}, F_{1}, F_{2}$ dengan variable terikat $Y$ berjalan satu arah. 


\section{KESIMPULAN}

Karakteristik sosial ekonomi rumah tangga miskin di Desa Cilallang Kecamatan Kamanre Kabupaten Luwu rata-rata memiliki jumlah penghasilan dengan nilai signifikan dan $\beta$ yang berbeda-beda yang dilihat dari setiap variabel bebas yang memiliki nilai positif dan negatif dan tidak semua variabel hasil penelitian berpengaruh terhadap jumlah penghasilan tetapi ada juga yang berpengaruh. Dimana untuk pendidikan terakhir ada pengaruh terhadap jumlah penghasilan sedangkan pekerjaan, usia, jumlah anak, dan jenis kelamin tidak ada pengaruh terhadap jumlah penghasilan. Sementara selisih antara nilai minimum dan maksimum pada masing-masing variabel berbeda jauh. Hal ini mengindikasikan bahwa terjadi ketidakmerataan jumlah penghasilan perbulan yang ada di Kabupaten/Kota pada wilayah tersebut.

Berdasarkan penelitian kemiskinan di Desa Cilallang Kecamatan Kamanre Kabupaten Luwu, hanya ada beberapa variabel yang signifikan dalam mencirikan rumah tangga miskin. Hal ini disebabkan oleh kondisi di wilayah tersebut yang bukan merupakan kantong kemiskinan. Oleh karena itu, bagi peneliti selanjutnya sebaiknya perlu melihat daerah-daerah yang memiliki tingkat kemiskinan yang tinggi.

\section{REFERENSI}

Cahyat, A., Gonner, C., dan Haug, M., 2007. Mengkaji Kemiskinan dan Kesejahteraan Rumah Tangga: Sebuah Panduan dengan Contoh dari Kutai Barat, Indonesia. Bogor: CIFOR.

Mulyanto. 2005. Kemiskinan dan Kebutuhan Pokok. Jakarta: Rajawali.

Suhardjo, A. J. 1997. Stratifikasi Kemiskinan dan Distribusi Pendapatan di Wilayah Pedesaan (Kasus Tiga Dusun Wilayah Karang Selatan, Gunung Merapi, Jawa Tengah). Majalah Geografi Indonesia No. 19 Th. 11, Maret 1997, Fakultas Geografi Universitas Gadjah Mada, Yogyakarta.

Prakosa. 2011. Klasifikasi Kesejahteraan Rumah Tangga di Provinsi Jawa Timur dengan Pendekatan Bootstrap Aggregating Classification and Regression Trees. Surabaya: Jurusan Statistika FMIPA-ITS 